\title{
AWARENESS ABOUT ANAESTHESIA AMONGST THE LAY PUBLIC
}

\author{
Malarvizhi Arumugam Chandrasekharan', Sree Ranjini Sudhakar ${ }^{2}$
}

${ }_{1}^{1}$ Associate Professor, Department of Anaesthesiology, Tagore Medical College Hospital, Affiliated to Tamilnadu Dr. MGR Medical University, Chennai, Tamilnadu.

${ }^{2}$ Associate Professor, Department of Anaesthesiology, Tagore Medical College Hospital, Affiliated to Tamilnadu Dr. MGR Medical University, Chennai, Tamilnadu.

\begin{abstract}
BACKGROUND

Anaesthesiologists today are playing a decisive role in patient management with advances in interventional techniques using ultrasound, newer safer drugs and have also moved to arenas such as critical care, resuscitation and pain management. But the general population does not seem to be aware of this. Their various misconceptions regarding anaesthesia results in them making bad choices, which can be detrimental to them.

Aims and Objectives- This cross-sectional study was undertaken to study the knowledge/ awareness about anaesthesiologist, anaesthesiology and different techniques of anaesthesia amongst the lay public.
\end{abstract}

\section{MATERIALS AND METHODS}

The study was conducted in 230 individuals who satisfied the eligibility criteria and were divided into five groups based on their literacy level. A set of twenty questions were given to each and answers evaluated. One-Way ANOVA (Analysis of variance) for randomised group was used to find the correlation between patient's knowledge about anaesthesia and increasing literacy levels. In our study, the ' $p$ ' value thus calculated was $<0.05$ and hence significant.

\section{RESULTS}

The performance of each group based on their answers to the questionnaire, calculation of marks and statistical analysis. Their knowledge and awareness about anaesthesia stands at 6.59\% for Group I, 31.85\% for Group II, 57.32\% for Group III, 70.55\% for Group IV and $82.50 \%$ for Group V. This shows increase in knowledge about anaesthesia with increase in literacy levels. This correlation is also being statistically significant.

\section{CONCLUSION}

Awareness about anaesthesiologists and anaesthesia is fairly low amongst lay public, better in people with higher literacy levels, but still needs to be improved. Measures need to be taken for educating them, to help them make better choices and allay their fears and misconceptions regarding the same.

\section{KEYWORDS}

Awareness, Anaesthesia, Survey, Lay Public, Literacy Level.

HOW TO CITE THIS ARTICLE: Chandrasekharan MA, Sudhakar SR. Awareness about anaesthesia amongst the lay public. J. Evolution Med. Dent. Sci. 2018;7(18):2252-2256, DOI: 10.14260/jemds/2018/507

\section{BACKGROUND}

Anaesthesiologists and Anaesthesia as a speciality has not got its due for a long time now. It is typically considered a 'hidden' speciality or 'behind the scenes' speciality, even though Anaesthesiologists today are playing a decisive role in patient management with advances in interventional techniques using ultrasound, newer safer drugs and have also moved to arenas such as critical care, resuscitation and pain management. But the general population does not seem to be aware of this. Their various misconceptions regarding anaesthesia results in making bad choices, which can be detrimental to them. Additionally, the problems of image and status of the anaesthesiologists in the eyes of the medical and lay communities are not new. ${ }^{1}$

'Financial or Other Competing Interest': None.

Submission 22-03-2018, Peer Review 15-04-2018,

Acceptance 21-04-2018, Published 30-04-2018.

Corresponding Author:

Dr. Sree Ranjini Sudhakar,

No. 275-276, $11^{\text {th }}$ Cross,

Jayendra Nagar, Sembakkam,

Chennai-600073, Tamilnadu.

E-mail:dr.s.sreeranjani@gmail.com

DOI: $10.14260 /$ jemds $/ 2018 / 507$
With the changing health care environment and advancement in anaesthesiology, the patients and general public needs to be educated. ${ }^{2}$ This public education is necessary, so that the patients can make informed and right decisions regarding their choice of anaesthetic techniques and not be perturbed by myths surrounding them. But before this, the level of awareness about anaesthesia amongst the lay public needs to be evaluated. Hence, the present study.

\section{Aims and Objectives}

This cross-sectional study was undertaken to study the knowledge/ awareness about anaesthesiologist, anaesthesiology and different techniques of anaesthesia amongst the lay public.

\section{MATERIALS AND METHODS \\ Study Design \\ Cross-sectional study.}

\section{Period of Study}

Six months.

\section{Inclusion Criteria}

Persons between the ages of 18 - 80 years. 


\section{Exclusion Criteria}

Persons who refused to participate, those who are nurses or working in any capacity in a hospital or health care unit, persons who have themselves undergone any surgery previously, those hard of hearing, mentally subnormal patients, those with psychiatric problems and those unable to answer questions due to poor medical condition were excluded.

\section{Methodology}

Following prior ethical committee approval, consecutive patients and their attendants, who attended the general outpatient clinics and satisfied the eligibility criteria were involved in the study. They numbered 230. This sample was chosen as a matter of convenience. They were asked to sign the written informed consent form and then were administered the questionnaire in both English and the regional language Tamil. For those unable to read, the questionnaire was read out and answers marked. The questionnaire with responses is in Table 2.

The first part of the questionnaire was on demographics including the literacy level. The participants were then asked if they have heard of Anaesthesiologist and Anaesthesia? If the answer was NO to both Anaesthesiologist and Anaesthesia, then no further questions were asked. If the answer was YES to both, then all further questions were asked. If they had heard of Anaesthesia alone, but not separate personnel administering it, then questions 10 to 20 were asked. Such people were then asked an additional question "Who do you think gives Anaesthesia?" The choices for the answer being "Surgeon, Nurse, Technician or Do Not Know." It is improbable that people know of anaesthesiologist, but not about anaesthesia; as the knowledge that there are separate personnel for a separate skill exists, only if the existence of that separate skill is acknowledged and understood. Never the less, we retained that question. After the participants completed the questionnaire, the answers were evaluated. For each correct answer, one mark was given. If they marked do not know or gave the wrong answer, then zero mark was given. The total was for 20 marks. The additional question which was given to people who had heard of anaesthesia but not Anaesthesiologist was not considered for giving marks, as the question has no correct answer in the choice, but was asked to evaluate the general misconception regarding the same.

\section{Statistical Methods}

Using IBM Statistical Package for Social Sciences (SPSS) 16 software; One-Way ANOVA (Analysis of Variance) test was used to find the correlation between patient's knowledge about anaesthesia and increasing literacy levels. A 'p' value < 0.05 was considered significant. Mean scores obtained by each group were used for statistical analysis.

\section{Statistical Analysis}

Of the 230 people who enrolled in the study, 128 were females and 102 were males. Based on the literacy level, they were divided into five groups. People who never attended school were categorised under Group- I or "Illiterate group," Group- II or "Primary school group" when class studied was between $1^{\text {st }}-5^{\text {th }}$ std.; Group- III or "Middle- Higher secondary school group" when class studied was between $6^{\text {th }}-12^{\text {th }}$ std.; Group- IV if an Undergraduate student or completed Graduation and Group- V if undergoing Post-Graduation studies or completed Post-Graduation. The numbers in each group are as seen in Table 1.

\begin{tabular}{|c|c|c|c|c|c|c|}
\hline & $\begin{array}{c}\text { Group- I or } \\
\text { “Illiterate } \\
\text { Group" }\end{array}$ & $\begin{array}{c}\text { Group- II or } \\
\text { "Primary School } \\
\text { Group" }\end{array}$ & $\begin{array}{c}\text { Group- III or } \\
\text { "Middle-Higher } \\
\text { Secondary School } \\
\text { Group" }\end{array}$ & $\begin{array}{c}\text { Group- IV } \\
\text { if an Undergraduate } \\
\text { (UG) Student or } \\
\text { Completed UG }\end{array}$ & $\begin{array}{c}\text { Group- V if a Post- } \\
\text { Graduation (PG) } \\
\text { Student or } \\
\text { Completed PG }\end{array}$ & $\begin{array}{c}\text { Row } \\
\text { Total }\end{array}$ \\
\hline Females & 28 & 32 & 24 & 33 & 11 & 128 \\
\hline Males & 16 & 22 & 19 & 30 & 15 & 102 \\
\hline Column Total & $\mathbf{4 4}$ & $\mathbf{5 4}$ & $\mathbf{4 3}$ & $\mathbf{6 3}$ & $\mathbf{2 6}$ & $\mathbf{2 3 0}$ \\
\hline \multicolumn{7}{|c|}{ Table 1. Groups and Participants in Each } \\
\hline
\end{tabular}

The responses to the Questionnaire are in Table 2.

\begin{tabular}{|c|c|c|c|c|c|c|c|}
\hline $\begin{array}{l}\text { Sl. } \\
\text { No. }\end{array}$ & \multicolumn{2}{|c|}{ Questionnaire and Responses } & $\begin{array}{c}\text { Group- I } \\
n=44(\%)\end{array}$ & $\begin{array}{l}\text { Group- II } \\
n=54(\%)\end{array}$ & $\begin{array}{l}\text { Group- III } \\
n=43(\%)\end{array}$ & $\begin{array}{l}\text { Group- IV } \\
n=63(\%)\end{array}$ & $\begin{array}{l}\text { Group- V } \\
n=26(\%)\end{array}$ \\
\hline 1 & \multicolumn{2}{|c|}{ Heard of Anaesthesiologist } & $8(18.18)$ & $42(92.59)$ & $41(95.34)$ & $63(100)$ & $26(100)$ \\
\hline \multirow{3}{*}{2} & \multirow{3}{*}{ Are Anaesthesiologists doctors? } & Yes & $8(18.18)$ & $31(57.4)$ & $41(95.34)$ & $63(100)$ & $26(100)$ \\
\hline & & No & & $5(9.25)$ & & & \\
\hline & & Do not know & & $6(11.11)$ & & & \\
\hline \multirow{3}{*}{3} & \multirow{3}{*}{$\begin{array}{c}\text { Do you think they study a } \\
\text { separate course to become } \\
\text { Anaesthesiologists? }\end{array}$} & Yes & $3(6.81)$ & $31(57.4)$ & 27 (62.79) & $63(100)$ & $26(100)$ \\
\hline & & No & & & $1(2.32)$ & & \\
\hline & & Do not know & $5(11.36)$ & $11(20.37)$ & $13(30.23)$ & & \\
\hline \multirow{6}{*}{4} & $\begin{array}{c}\text { What do you think is the role of } \\
\text { Anaesthesiologist in your/ } \\
\text { patient's treatment? }\end{array}$ & & & & & & \\
\hline & \multirow{2}{*}{$\begin{array}{c}\text { Give medicines to put patient to } \\
\text { sleep }\end{array}$} & Yes & $8(18.18)$ & $42(92.59)$ & $41(95.34)$ & $63(100)$ & $26(100)$ \\
\hline & & No & & & & & \\
\hline & \multirow{2}{*}{ Assist the surgeon } & Yes & & & & & \\
\hline & & No & & & & & \\
\hline & Do not know & & & & & & \\
\hline \multirow[b]{2}{*}{5} & \multirow{2}{*}{$\begin{array}{c}\text { Will anaesthesiologist stay } \\
\text { inside the OT after giving } \\
\text { anaesthesia? }\end{array}$} & Yes & $3(6.81)$ & $25(46.29)$ & $30(69.76)$ & $41(65.07)$ & $24(92.31)$ \\
\hline & & No & $\begin{array}{c}2 \\
(4.5)\end{array}$ & $\begin{array}{c}11 \\
(20.37)\end{array}$ & $\begin{array}{c}7 \\
(16.27)\end{array}$ & $\begin{array}{c}9 \\
(14.28)\end{array}$ & $\begin{array}{c}1 \\
(3.8)\end{array}$ \\
\hline
\end{tabular}




\begin{tabular}{|c|c|c|c|c|c|c|c|}
\hline & & Do not know & $3(6.81)$ & $6(11.11)$ & $4(9.3)$ & $13(20.63)$ & $1(3.8)$ \\
\hline \multirow{6}{*}{6} & \multirow{6}{*}{$\begin{array}{c}\text { Does an anaesthesiologist do } \\
\text { anything in the postoperative } \\
\text { period? }\end{array}$} & $\begin{array}{l}\text { Monitors the } \\
\text { patient }\end{array}$ & & $16(29.62)$ & $20(46.51)$ & & $5(19.23)$ \\
\hline & & $\begin{array}{c}\text { Takes care of } \\
\text { pain }\end{array}$ & $5(11.36)$ & 11 (20.37) & $8(18.60)$ & $11(17.46)$ & \\
\hline & & \begin{tabular}{|c|} 
Takes care of \\
complications
\end{tabular} & & & $9(20.93)$ & $27(42.85)$ & \\
\hline & & \begin{tabular}{|c|} 
More than one \\
of the above
\end{tabular} & & & $4(9.3)$ & 25 (39.68) & 21 (80.76) \\
\hline & & Nothing & $1(2.27)$ & $8(14.81)$ & $5(11.62)$ & & \\
\hline & & Do not know & $2(4.5)$ & $7(12.96)$ & $5(11.62)$ & & \\
\hline \multirow{3}{*}{7} & \multirow{3}{*}{$\begin{array}{c}\text { Other than Operation theatre, } \\
\text { does an anaesthesiologist work } \\
\text { anywhere else? }\end{array}$} & Yes & & $4(7.4)$ & $17(39.53)$ & $35(55.55)$ & $18(69.23)$ \\
\hline & & No & & & $9(20.93)$ & $13(20.63)$ & \\
\hline & & Do not know & $8(18.18)$ & $38(70.37)$ & $13(30.23)$ & $15(23.80)$ & $8(30.76)$ \\
\hline \multirow{5}{*}{8} & \multirow{5}{*}{$\begin{array}{c}\text { If yes, which other field are you } \\
\text { aware? }\end{array}$} & ICU & \multirow{5}{*}{$\begin{array}{c}\text { Not } \\
\text { applicable }\end{array}$} & $4(7.4)$ & $11(25.58)$ & $27(42.85)$ & $7(26.92)$ \\
\hline & & Pain & & & & $1(1.5)$ & $1(3.8)$ \\
\hline & & Emergency & & & $5(11.62)$ & $1(1.5)$ & $3(11.53)$ \\
\hline & & $\begin{array}{c}\text { More than one } \\
\text { of the above }\end{array}$ & & & & $6(9.5)$ & 7 (26.92) \\
\hline & & Any other & & & $1(2.3)-$ as GP & & \\
\hline 9 & \multirow{5}{*}{$\begin{array}{c}\text { What types of Anaesthesia you } \\
\text { know? }\end{array}$} & & $8(18.18)$ & $50(92.59)$ & $41(95.34)$ & $63(100)$ & $26(100)$ \\
\hline \multirow{4}{*}{10} & & Do not know & & & & & \\
\hline & & General & & $18(33.33)$ & $5(11.62)$ & & \\
\hline & & Regional & $6(13.63)$ & $27(50)$ & $3(6.9)$ & & \\
\hline & & $\begin{array}{l}\text { Both General } \\
\text { and Regional }\end{array}$ & $2(4.5)$ & $5(9.2)$ & 33 (76.74) & $63(100)$ & $26(100)$ \\
\hline \multirow{2}{*}{11} & \multirow{2}{*}{$\begin{array}{l}\text { Any idea about how General } \\
\text { Anaesthesia is given? }\end{array}$} & Yes & $2(4.5)$ & $11(20.37)$ & $38(88.37)$ & $63(100)$ & $26(100)$ \\
\hline & & No & $6(13.63)$ & $12(22.22)$ & & & \\
\hline \multirow{3}{*}{12} & \multirow{3}{*}{$\begin{array}{l}\text { Drugs used in General } \\
\text { Anaesthesia }\end{array}$} & $\begin{array}{c}\text { Only } \\
\text { inhalational } \\
\end{array}$ & $2(4.5)$ & 11 (20.37) & $5(11.62)$ & & \\
\hline & & $\begin{array}{c}\text { Only } \\
\text { intravenous }\end{array}$ & & & 7 (16.27) & $5(7.9)$ & \\
\hline & & Both & & & $26(60.46)$ & $58(92.06)$ & $26(100)$ \\
\hline 13 & $\begin{array}{l}\text { Can you name any drugs used } \\
\text { in General Anaesthesia (GA)? }\end{array}$ & & Nil & Nil & 3-chloroform & $\begin{array}{l}\text { 1-Ketamine } \\
\text { 8-chloroform }\end{array}$ & \begin{tabular}{|c|} 
4-Ketamine \\
11-chloroform \\
2-ether \\
\end{tabular} \\
\hline \multirow{2}{*}{14} & \multirow{2}{*}{$\begin{array}{l}\text { Any idea about how regional } \\
\text { anaesthesia is given? }\end{array}$} & Yes & $8(18.18)$ & $32(59.25)$ & $36(83.72)$ & $63(100)$ & $26(100)$ \\
\hline & & No & & & & & \\
\hline \multirow{2}{*}{15} & \multirow{2}{*}{$\begin{array}{l}\text { If yes, have you heard of } \\
\text { spinal/ epidural? }\end{array}$} & Yes & $8(18.18)$ & $32(59.25)$ & 36 (83.72) & $63(100)$ & $26(100)$ \\
\hline & & No & & & & & \\
\hline \multirow{3}{*}{16} & \multirow{3}{*}{$\begin{array}{c}\text { Do you think spinal/ epidural } \\
\text { can cause backache? }\end{array}$} & Yes & $5(11.36)$ & $18(33.33)$ & 27 (62.79) & $56(88.88)$ & $16(61.53)$ \\
\hline & & No & & $2(3.7)$ & & $2(3.1)$ & $7(26.92)$ \\
\hline & & Do not know & $3(6.8)$ & $12(22.22)$ & $9(20.93)$ & $5(7.9)$ & $3(11.53)$ \\
\hline \multirow{3}{*}{17} & \multirow[t]{3}{*}{ Which do you think is safer? } & GA & & $3(5.5)$ & $13(30.23)$ & $18(28.57)$ & $3(11.53)$ \\
\hline & & Regional & & $7(12.96)$ & $11(25.58)$ & $45(71.42)$ & $23(88.46)$ \\
\hline & & Do not know & $8(18.18)$ & $40(74.07)$ & $18(41.86)$ & & \\
\hline \multirow{3}{*}{18} & \multirow{3}{*}{\begin{tabular}{|c|} 
Is any special equipment \\
needed for giving anaesthesia?
\end{tabular}} & Yes & & $11(20.37)$ & $19(44.18)$ & $49(77.77)$ & $26(100)$ \\
\hline & & No & & $9(16.66)$ & $2(4.6)$ & & \\
\hline & & Do not know & $8(18.18)$ & $30(55.55)$ & $20(46.51)$ & $14(22.22)$ & \\
\hline & Can anaesthesia cause & Yes & & $17(31.48)$ & $34(79.06)$ & $63(100)$ & $26(100)$ \\
\hline 19 & complications? & No & & & $1(2.3)$ & & \\
\hline & & Do not know & $8(18.18)$ & $33(61.11)$ & $6(13.95)$ & & \\
\hline 20 & If yes, can you name any & & & $2(3.7)$ & $15(34.88)$ & $52(82.53)$ & $26(100)$ \\
\hline 20 & complications & & & Heart attack, & athing diffic & Back pain, $\mathrm{H}$ & dache, Death \\
\hline & & Table 2 & i. & and Respon & & & \\
\hline
\end{tabular}

\begin{tabular}{|c|c|c|c|}
\hline & Sum of Total Score & Mean Score & SD \\
\hline Group- In=44 & 58 & 1.31 & 0.0058 \\
\hline Group- II $\mathrm{n}=54$ & 344 & 6.37 & 0.0115 \\
\hline Group- II $\mathrm{n}=43$ & 493 & 11.46 & 0.0153 \\
\hline Group- IV $\mathrm{n}=63$ & 889 & 14.11 & 0.01 \\
\hline Group- V n= 26 & 429 & 16.50 & 0.02 \\
\hline
\end{tabular}

The ' $F$ ' value was found to be 624892.46296 . The ' $p$ ' value thus calculated being $<0.05$ and is significant. 


\section{RESULTS}

The performance of each group, based on their answers to the questionnaire, calculation of marks and statistical analysis; their knowledge and awareness about anaesthesia stands at $6.59 \%$ for Group I, 31.85\% for Group II, $57.32 \%$ for Group III, 70.55\% for Group IV and $82.50 \%$ for Group V. This shows increase in knowledge about anaesthesia with increase in literacy levels, this correlation also being statistically significant.

\section{DISCUSSION}

Development of anaesthesia and surgery go hand in hand. Advancements and development of anaesthesia as a specialty has enabled better surgical management. But a poor fund of knowledge regarding anaesthesia amongst lay public is a serious setback, which needs to be corrected.

In our study, the participants were initially asked if they have heard of Anaesthesiologist and Anaesthesia. As predicted, all persons who knew about anaesthesiologist knew something about anaesthesia, but not vice versa. As some people had heard of anaesthesia, but not about anaesthesiologist or a separate person administering it. Only $18.18 \%$ (8/44) in Group I, 92.59\% in Group II, 95.34\% in Group III and all people in Group IV (Graduate) and V (Postgraduate) knew something about anaesthesiologist and anaesthesia.

Of the 44 people in Group I, 8 who had heard of anaesthesiologist and anaesthesia were women, whose source of information had been that their close relative had undergone surgery and it was they who had been around peri-operatively. In Group II out of 54 people 50 had heard about anaesthesia, out of which only 42 were aware of an anaesthesiologist. When these 8 people who were unaware of an anaesthesiologist were asked the additional question as to who will administer anaesthesia, 3 said it is the surgeon. The other 5 people said they had never thought about it and maybe it is the nurse! In Group III, IV and V, all those who knew about anaesthesia were aware of anaesthesiologist. The source of information for all the people was varied such as from being around peri-operatively when a close relative underwent surgery and from movies, books and hearsay.

When participants were asked if anaesthesiologists are doctors, only $18 \%$ in the illiterate group in our study were aware of it. The other groups fared better though and all in the graduate and postgraduate groups knew them as Doctors. Fewer still knew that they needed to study a separate course to become anaesthesiologists. The knowledge of anaesthesiologists as Doctors is similar to a study by Mathur et al. $^{3}$ In certain studies conducted abroad, $50 \%$ to $88.7 \%$ people knew the anaesthesiologist as a doctor. ${ }^{4-6}$ All those who knew of anaesthesiologist were aware that they are personnel, who give medicines to put a patient to sleep.

The participants on being asked as to whether the Anaesthesiologist will stay in the Operating Room after administering anaesthesia, only $6.81 \%$ in Group I, $46.29 \%$ in Group II, 69.76\% in Group III, 65.07 in Group IV and 92.31\% in Group V said they stay. This was in contrast to the findings of the surveys conducted in developed countries, where a majority of patients felt that the anaesthesiologist stays during operation to look after their vitals. ${ }^{7}$ In many previous studies, role of the anaesthesiologists after induction was also not clear to many patients. ${ }^{8,9}$ Role of Anaesthesiologist in postoperative care and other arenas were also not clear to most in our study with $69.23 \%$ in Group V having some idea regarding the same and all other groups faring badly. This is similar to other studies.7,8 But of those who knew about other arenas of work, ICU-intensive care unit was most commonly mentioned.

The knowledge that anaesthetic procedures include both general and regional techniques was known to only $4.5 \%$ and $9.2 \%$ in Group I and II. But it is heartening to note that $76.74 \%$ in Group III and $100 \%$ in Groups IV and V were aware of this fact. The knowledge about how general and regional anaesthesia was administered was poor among Groups I and II with slightly better knowledge about Regional compared to General anaesthesia in them. The other three groups (III, IV and V) had better knowledge. Older drugs like chloroform and Ether as being still used was mentioned by all groups except Group I, who did not have the slightest bit of knowledge regarding this. Few in graduate and postgraduate participants even mentioned ketamine.

From Groups I to V, 11.36\%, 33.33\%, 62.79\%, 88.88\% and $61.53 \%$ were of the opinion that spinal anaesthesia can cause backache. According to a study by Schwabe ${ }^{10}$ in 245 patients, Persistent Back Pain after Spinal anaesthesia is almost exclusively associated with pre-existing back pain; new onset of back pain is a rare event; and patient's characteristics and technical factors play no significant role. Yet this misconception of Backache following previous spinal anaesthetic was the major cause for $13.4 \%$ patients refusing spinal anaesthesia in a series of more than 1000 patients. ${ }^{11}$

People need to be educated regarding this misconception. 5.5\%, 30.23\%, 28.57\% and $11.53 \%$ through Groups II to V believed that General anaesthesia was safer compared to regional. The illiterate Group I had absolutely no idea. The fact that anaesthesia can cause complications was known to none in the illiterate group, $31.08 \%$ and $79.06 \%$ in Group II and III knew. But $82.53 \%$ people in graduate and $100 \%$ in postgraduate group were aware. The commonly mentioned complications were Heart attack, Breathing difficulty, Back pain, Headache and Death. In a study by Usha Gurunathan, 8 nearly half of the patients felt that if the patient suffers from any other disease like diabetes, hypertension, asthma, epilepsy, liver dysfunction, is old, is a smoker or an alcoholic, then risks during anaesthesia increases.

The correlation between increasing literacy level and knowledge about anaesthesia in our study was statistically significant similar to other studies.3,12 Overall, from this survey it is clear that patients still have inadequate knowledge of anaesthesia and the role of anaesthetists and this corroborates with findings from other studies. ${ }^{13,14}$ But there is a desire amongst the patients to know about anaesthesia and anaesthesiologist, such as found out by studies all over the world.12,13 Hence, efforts should be taken to educate them.

The mode of education can be varied such as surgeons and anaesthetists educating patients by word of mouth when they come to the hospital, as also through the electronic and print media. The latter is a largely under-utilised modality, but has immense potential. The anaesthesiologists themselves need to spend more time preoperatively and explain what patients can expect in the Operating Room and about the anaesthetic procedures. Visiting the patients postoperatively will also have a tremendous impact. Knowing in 
advance that anaesthetists will be primarily responsible for treatment and being aware of the skills and experience of anaesthesiologists might help patients understand what care is available, its scope, its limitations and in this way some fears and anxieties may be allayed. 5 Better awareness about anaesthesia and anaesthesiologists amongst lay public will not only help the patients, but also anaesthesiologists will receive better recognition for their expertise and ultimately making them proud of the significant role they play.

\section{CONCLUSION}

Awareness about anaesthesiologists and anaesthesia is fairly low amongst lay public, better in people with higher literacy levels, but still needs to be improved. Measures need to be taken for educating them, to help them make better choices and allay their fears and misconceptions regarding the same.

\section{ACKNOWLEDGEMENTS}

Sincere thanks to Dr. V. Oviya and Dr. R. Sree Varshini, Junior Residents of our department for helping in data collection.

\section{REFERENCES}

[1] Armitage EN. The public image of the speciality [letter]. Anaesthesia 1978;33(1):64-5.

[2] Klafta JM, Roizen MF. Current understanding of the patients' attitudes toward and preparation for anesthesia: a review. Anesth Analg 1996;83(6):131421.

[3] Mathur SK, Dube SK, Jain S. Knowledge about anaesthesia and anaesthesiologist amongst general population in India. Indian J Anaesth 2009;53(2):17986.

[4] Keep PJ, Jenkins JR. As others see us: the patients' view of the anaesthetists. Anaesthesia 1978;33(1):43-5.
[5] Swinhoe CF, Groves ER. Patients' knowledge of anaesthetic practice and role of anaesthetists. Anaesthesia 1994;49(2):165-6.

[6] Hume MA, Kennedy B, Asbury AJ. Patient knowledge of anaesthesia and peri-operative care. Anaesthesia 1994;49(8):715-8.

[7] Herman CR. An appraisal of anaesthetist - patient relationship. Anaesthesia 1978;33(1):45-8.

[8] Gurunathan U, Jacob R. The public's perception of anaesthesiologists - Indian attitudes. Indian J Anaesth 2004;48(6):456-60.

[9] Shevde K, Panagopoulos G. A survey of 800 patient's knowledge, attitudes and concerns regarding anesthesia. Anesth Analg 1991;73(2):190-8.

[10] Schwabe K, Hopf HB. Persistent back pain after spinal anaesthesia in the non-obstetric setting: incidence and predisposing factors. British Journal of Anaesthesia 2001;86(4):535-9. https://doi.org/10.1093/bja/86.4.535

[11] Butler R, Fuller J. Back pain following epidural anaesthesia in labour. Can J Anaesthesia 1998;45(8):724-8.

[12] Baaj J, Takrouri M, Hussein B, et al. How much surgical patients at The King Khalid University Hospital (KKUH) know about their anesthesia and anesthesiologists? The Internet Journal of Health 2005;4:2 www.ispub.com.

[13] Chew STH, Tan T, Tan SS, et al. A survey of patients' knowledge of anaesthesia and perioperative care. Singapore Med J 1998;39(9):399-402.

[14] Hariharan S, Merritt-Charles L, Chen D. Patient perception of the role of anaesthesiologists: a perspective from the Caribbean. J Clin Anaesth 2006;18(7):504-9. 